\title{
Sucrose or honey at breakfast have no additional acute hyperglycaemic effect over an isoglucidic amount of bread in Type 2 diabetic patients
}

\author{
F. Bornet ${ }^{1}$, M.J. Haardt ${ }^{1,2}$, D. Costagliola ${ }^{2}$, A. Blayo ${ }^{1}$ and G. Slama ${ }^{1}$ \\ ${ }^{1}$ Department of Diabetes, Hôtel-Dieu Hospital, Paris, and ${ }^{2}$ Unité de Recherche Statistique INSERM U 21, Villejuif, France
}

\begin{abstract}
Summary. Exclusion of simple sugars from the diabetic diet is not always followed by patients and may not even be as crucial as was hitherto thought. We tested three types of mixed breakfasts $(400 \mathrm{kcal}, 50 \mathrm{~g} \mathrm{HCO})$ including an isoglucidic amount either of white bread $(30 \mathrm{~g})$, honey $(20 \mathrm{~g})$ or sucrose $(15 \mathrm{~g})$, at the critical morning period i.e. for breakfast, in a group of 21 Type 2 (non-insulin-dependent) diabetic patients ( 6 well- and 15 badly controlled). Mean plasma glucose and insulin levels were comparable on the three occasions: respectively with bread, sucrose and honey, peak glucose values were $18 \mathrm{mmol} / 1,17.7 \mathrm{mmol} / 1$ and $17.5 \mathrm{mmol} / 1$ in the uncontrolled group versus $13.9 \mathrm{mmol} / 1, \quad 12.8 \mathrm{mmol} / 1$ and $12.7 \mathrm{mmol} / \mathrm{l}$ in the well-controlled group. Peak insulin values were $33.6 \mathrm{mU} / 1,34.0 \mathrm{mU} / 1$ and $36.3 \mathrm{mU} / 1(p>0.05)$ in uncontrolled patients against $57.5 \mathrm{mU} / 1,54.8 \mathrm{mU} / 1$ and $52.5 \mathrm{mU} / 1$
\end{abstract}

in well-controlled subjects $(p>0.05)$. The mean increment in peak plasma glucose values for the three breakfasts was as follows: $6.9 \mathrm{mmol} / 1,6.3 \mathrm{mmol} / 1$ and $6.2 \mathrm{mmol} / 1$ for the uncontrolled group against $7.2 \mathrm{mmol} / 1,5.9 \mathrm{mmol} / 1$ and $6.2 \mathrm{mmol} / 1$ in well-controlled subjects; the mean increment in peak plasma insulin levels was $21.8 \mathrm{mU} / 1,22.0 \mathrm{mU} / 1$ and $24.2 \mathrm{mU} / 1$ in the controlled group versus $38.2 \mathrm{mU} / 1,32.0 \mathrm{mU} / 1$ and $34.7 \mathrm{mU} / \mathrm{l}$ in the well-controlled subjects, all values being non-significantly different $(p>0.05)$. We conclude that, in acute conditions, simple sugars have no additional hyperglycaemic effect over an isoglucidic amount of bread in well- and in badly controlled Type 2 diabetic patients, even at breakfast.

Key words: Sucrose; honey, simple sugar, diabetic diet, Type 2 diabetes, plasma glucose, plasma insulin.
Exclusion of simple sugars from the diabetic diet is recommended by almost all international diabetic associations [1-3]. This recommendation is known - but to a lesser extent followed - by most diabetic patients [4] and is based on the hypothesis that mono- and disaccharides induce faster and higher blood glucose levels than starch. However, several studies, some over a decade old, have shown that certain sugars, even when eaten alone are less hyperglycaemic than some starchcontaining foods in normal subjects $[5,6]$ and in diabetic patients [7-11]. We have recently shown that $20 \mathrm{~g}$ sucrose at the end of a regular mixed meal at lunch had no additional acute hyperglycaemic effect over an isocaloric amount of starch in well controlled Types 1 and 2 diabetic patients [12].

We decided to evaluate the acute metabolic effects of two current simple sugars in Type 2 diabetics at a critical period of the day, i.e. in the morning [13], in both uncontrolled and well-controlled Type 2 diabetics.

\section{Subjects and methods}

Twenty-one Type 2 diabetic patients were studied whose characteristics are given in Table 1. Fifteen (group A) were hospitalized to improve bad metabolic control [fasting and $2-\mathrm{h}$ post prandial plasma glucose levels for the 3 days of experimentation were above $8 \mathrm{mmol} / \mathrm{l}$, and mean ( $\pm \mathrm{SEM}$ ) $\mathrm{HbA}_{1 \mathrm{c}} 9.7 \pm 0.5 \%$ ] (normal range: 4 to $6 \%$ ). Six others, carefully matched for age, BMI and diabetes duration, and considered as reasonably well-controlled (group B) (fasting and 2-h post prandial lunchtime plasma glucose values below $8 \mathrm{mmol} / \mathrm{l}$ for the 3 days of experimentation; mean $\mathrm{HbA} 1 \mathrm{c} 7.1 \pm 0.4 \%$ ) accepted a short hospitalization for the study. Body weight, diet, physical activity and therapy were stable for at least 1 week before testing, their usual therapy being continued throughout the experiment and taken before the test meal as usual where indicated.

All gave informed consent to participate in the study (approved by the Hospital Ethical Committee).

Each patient, serving as his or her own control, was tested on 3 consecutive days, in a random order permitting a Latin square study. At 08.00 hours after an overnight fast, patients ate a mixed breakfast of $70 \mathrm{~g}$ white bread, $10 \mathrm{~g}$ butter, $30 \mathrm{~g}$ camembert cheese, $250 \mathrm{ml}$ of decaffeinated coffee and either an additional $30 \mathrm{~g}$ white bread, $15 \mathrm{~g}$ sucrose of $20 \mathrm{~g}$ honey. Each breakfast $(400 \mathrm{kcal})$ thus contained $50 \mathrm{~g}$ carbohydrate, $16 \mathrm{~g}$ fat and $12 \mathrm{~g}$ protein according to reference tables [14]. The composition of the three breakfasts is summarized in Table 2. Each breakfast was taken in $10 \mathrm{~min}$. Blood samples were drawn from an indwelling catheter every $15 \mathrm{~min}$ between -30 and $+60 \mathrm{~min}$ after the beginning of the meal and then every $30 \mathrm{~min}$ until $180 \mathrm{~min}$ after the start of the meal. Samples were immediately centrifuged and plasma frozen at $18^{\circ} \mathrm{C}$ for ultimate assay. Plasma glucose was assayed using a glucose oxidase method (Beckman Autoanalyzer II, Beckman instr., Fullerton, USA) and insulin using a radio-immuno assay with charcoal separation. All samples were assayed in the same batch. Insulin intra assay reproducibility was $6 \% . \mathrm{HbA}_{1 c}$ was assayed according to Trirelli. 
Table 1. Clinical characteristics of the patients

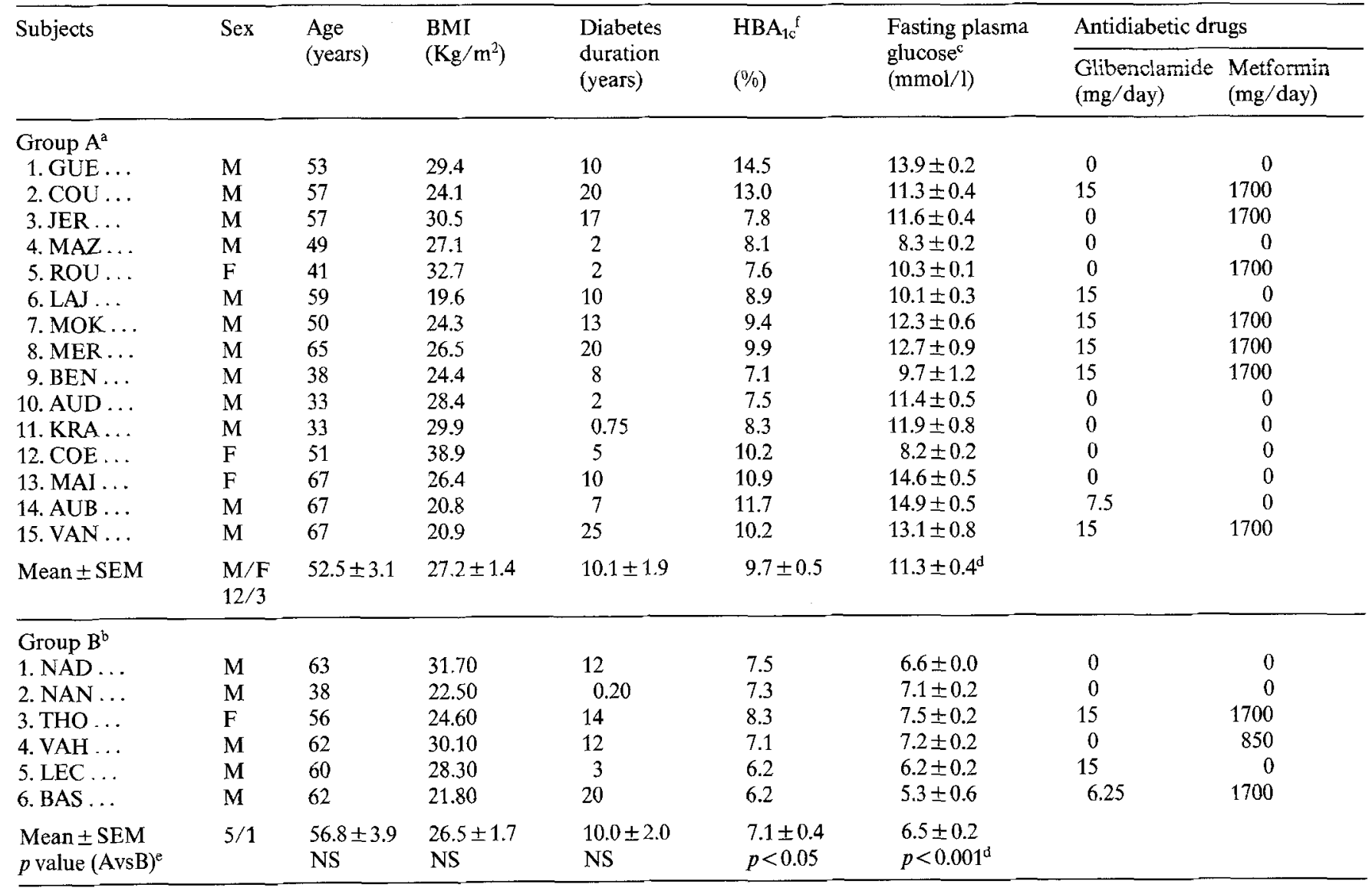



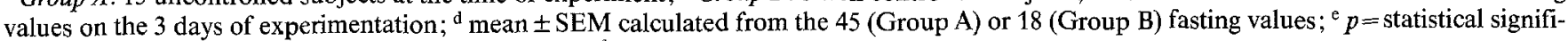
cance (Student's $t$ test) NS $=$ non significant $(p>0.05) ;{ }^{f}$ normal range 4-6\%

Table 2. Composition of the three breakfasts

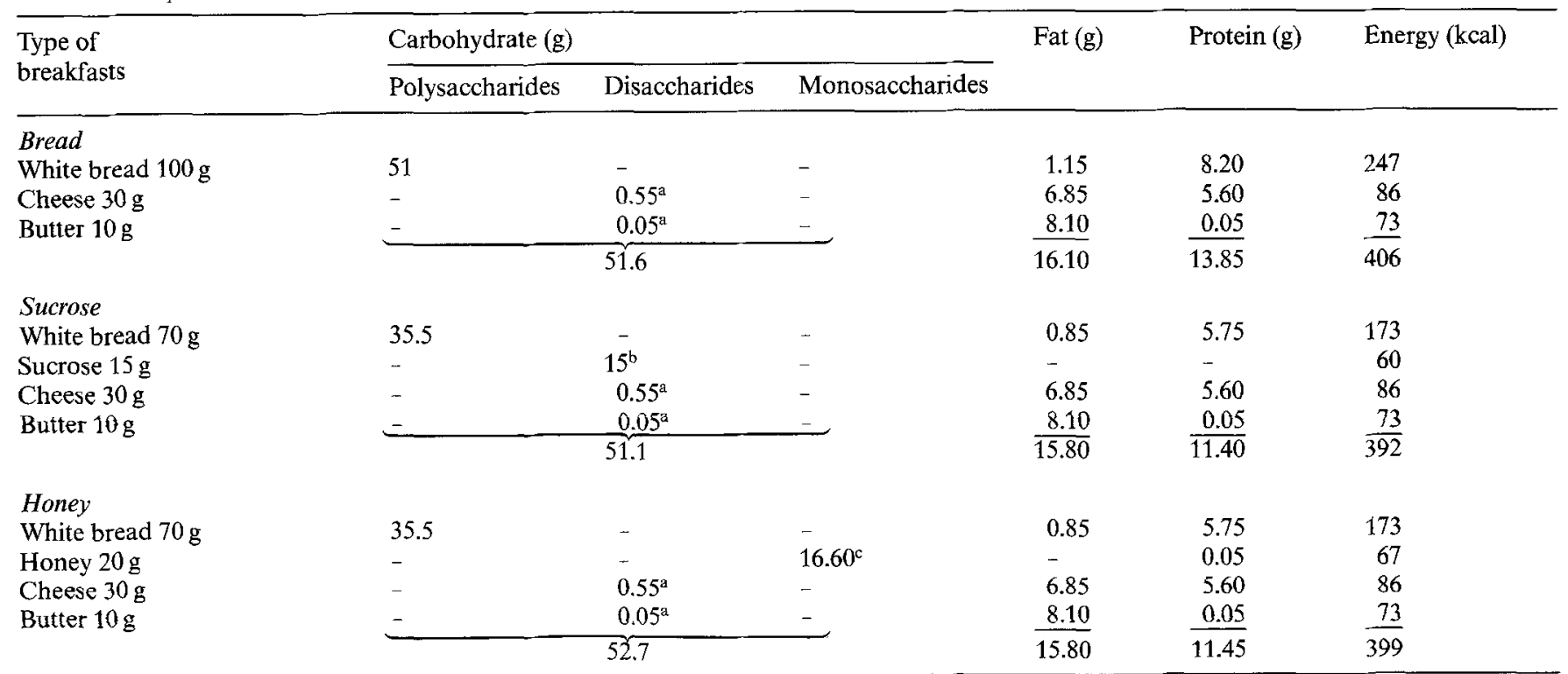

${ }^{a}$ Lactose; ${ }^{\mathrm{b}}$ saccharose; ${ }^{\mathrm{c}}$ fructose $53 \%$ - glucose $47 \%$ 


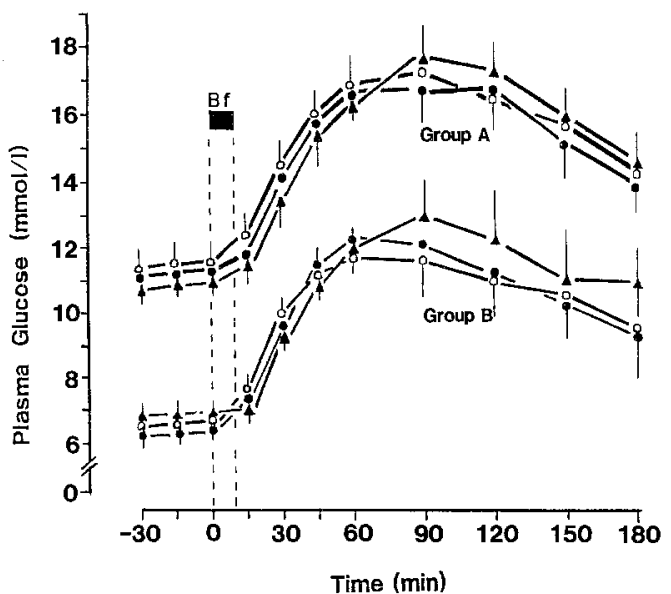

Fig. 1. Mean plasma glucose profiles in 15 uncontrolled (group A) and 6 well-controlled (group B) Type 2 diabetic patients receiving at breakfast (Bf) either $20 \mathrm{~g}$ honey $(\longrightarrow), 15 \mathrm{~g}$ sucrose $(\mathrm{O}-\mathrm{O})$, an extra $30 \mathrm{~g}$ white bread ( $\mathbf{A})$. Bars indicate $1 \mathrm{SEM}$



Fig. 2. Mean plasma insulin profiles in 15 uncontrolled (group A) and 6 well-controlled (group B) Type 2 diabetic patients receiving at breakfast $(\mathrm{Bf})$ either $20 \mathrm{~g}$ honey $(\longrightarrow), 15 \mathrm{~g}$ sucrose $(\mathrm{O}-\mathrm{O})$, an extra $30 \mathrm{~g}$ white bread ( $\mathbf{\Lambda}$ )

Table 3. Characteristics of mean plasma glucose variations within $180 \mathrm{~min}$ of start of breakfast

\begin{tabular}{|c|c|c|c|c|c|}
\hline & a & Bread & Sucrose & Honey & Significance ${ }^{b}$ \\
\hline $\begin{array}{l}\text { Peak plasma glucose } \\
(\mathrm{mmol} / \mathrm{l})\end{array}$ & $\begin{array}{l}\text { Group A } \\
\text { Group B } \\
\text { Significance }\end{array}$ & $\begin{array}{l}18.0 \pm \quad 0.8 \\
13.9 \pm 0.9 \\
p<0.01\end{array}$ & $\begin{array}{c}17.7 \pm \quad 0.9 \\
12.8 \pm \quad 0.8 \\
p<0.005\end{array}$ & $\begin{array}{c}17.5 \pm \quad 0.8 \\
12.7 \pm \quad 0.9 \\
p<0.001\end{array}$ & $\begin{array}{l}\text { NS } \\
\text { NS }\end{array}$ \\
\hline $\begin{array}{l}\text { Peaking time } \\
\text { (min) }\end{array}$ & $\begin{array}{l}\text { Group A } \\
\text { Group B } \\
\text { Significance }\end{array}$ & $\begin{array}{l}86 \pm 6 \\
95 \pm 12 \\
\mathrm{NS}\end{array}$ & $\begin{array}{l}91 \pm 9 \\
75 \pm 16 \\
\text { NS }\end{array}$ & $\begin{array}{l}82 \pm 7 \\
77 \pm 11 \\
\mathrm{NS}\end{array}$ & $\begin{array}{l}\text { NS } \\
\mathrm{NS}\end{array}$ \\
\hline $\begin{array}{l}\text { Areas increment } \\
\text { above starting value } \\
\left(\mathrm{mmol} \cdot 1^{-1} \cdot \min ^{-1}\right)\end{array}$ & $\begin{array}{l}\text { Group A } \\
\text { Group B } \\
\text { Significance }\end{array}$ & $\begin{array}{l}807.4 \pm 101.2 \\
796.3 \pm 160.2 \\
\text { NS }\end{array}$ & $\begin{array}{l}740.0 \pm 83.4 \\
755.1 \pm 176.2 \\
\text { NS }\end{array}$ & $\begin{array}{l}705.7 \pm 83.0 \\
730.7 \pm 158.0 \\
\text { NS }\end{array}$ & $\begin{array}{l}\text { NS } \\
\text { NS }\end{array}$ \\
\hline
\end{tabular}

${ }^{a}$ Group A: $n=15$; badly controlled diabetics; Group B: $n=6$; well controlled diabetics; ${ }^{\mathrm{b}}$ significance: analysis of variance; ${ }^{\mathrm{c}}$ significance: Student's t test for unpaired data; ${ }^{\mathrm{d}} \mathrm{NS}=$ non significant $(p>0.05)$

Table 4. Characteristics of mean insulin plasma variations within $180 \mathrm{~min}$ of start of breakfast

\begin{tabular}{|c|c|c|c|c|c|}
\hline & a & Bread & Sucrose & Honey & Significance ${ }^{b}$ \\
\hline $\begin{array}{l}\text { Peak insulin values } \\
\quad(\mathrm{mU} / 1)\end{array}$ & $\begin{array}{l}\text { Group A } \\
\text { Group B } \\
\text { Significance }\end{array}$ & $\begin{array}{l}33.6 \pm \quad 4.0 \\
57.5 \pm 10.1 \\
p<0.02\end{array}$ & $\begin{array}{l}34.0 \pm \\
54.8 \pm \\
p=0.02\end{array}$ & $\begin{array}{ll}36.3 \pm & 4.4 \\
52.5 \pm & 6.3 \\
\text { NS }\end{array}$ & $\begin{array}{l}\text { NS } \\
\text { NS }\end{array}$ \\
\hline $\begin{array}{l}\text { Peaking time } \\
\text { (min) }\end{array}$ & $\begin{array}{l}\text { Group A } \\
\text { Group B } \\
\text { Significance }\end{array}$ & $\begin{array}{c}99 \pm 10 \\
105 \pm 17 \\
\text { NS }\end{array}$ & $\begin{array}{l}94 \pm 9 \\
80 \pm 16 \\
\text { NS }\end{array}$ & $\begin{array}{l}86 \pm 13 \\
95 \pm 18 \\
\mathrm{NS}\end{array}$ & $\begin{array}{l}\text { NS } \\
\text { NS }\end{array}$ \\
\hline $\begin{array}{l}\text { Areas increment above } \\
\text { starting value } \\
\left(\mathrm{mU} \cdot 1^{-1} \cdot \min ^{-1}\right)\end{array}$ & $\begin{array}{l}\text { Group A } \\
\text { Group B } \\
\text { Significance }\end{array}$ & $\begin{array}{c}2324 \quad \pm 388 \\
4655 \quad \pm 829 \\
p<0.005\end{array}$ & $\begin{array}{c}2313 \pm 355 \\
4087 \pm 404 \\
p<0.02\end{array}$ & $\begin{array}{c}2306 \pm 397 \\
4585 \pm 447 \\
p<0.005\end{array}$ & $\begin{array}{l}\text { NS } \\
\text { NS }\end{array}$ \\
\hline
\end{tabular}

${ }^{a}$ Group A: $n=15$; badly controlled diabetics; Group B: $n=6$; well controlled diabetics; ${ }^{\mathrm{b}}$ significance: analysis of variance; ${ }^{\mathrm{c}}$ significance: Student's $\mathrm{t}$ test for unpaired data; ${ }^{\mathrm{d}} \mathrm{NS}=$ non significant $(p>0.05)$ 
Statistical analysis used the analysis of variance with three factors (subjects, breakfast content and order) and the Student's test for unpaired data as indicated. Results are given as mean \pm standard error of the mean $(m \pm S E M)$.

\section{Results}

Figure 1 and Table 3 give the mean plasma glucose profiles after each breakfast containing a supplement of white bread, sucrose or honey in the 15 uncontrolled Type 2 diabetics (group A) and in the 6 well-controlled patients (group B).

In group A mean starting fasting plasma glucose values were comparable before the extra white bread, sucrose and honey breakfasts, i. e. respectively: $11.2 \pm$ $0.6 \mathrm{mmol} / 1 \quad(201 \pm 12 \mathrm{mg} / 100 \mathrm{ml}) ; \quad 11.4 \pm 0.6 \mathrm{mmol} / 1$ $(206 \pm 12 \mathrm{mg} / 100 \mathrm{ml}) ; 11.3 \pm 0.7 \mathrm{mmol} / 1(204 \pm 13 \mathrm{mg} /$ $100 \mathrm{ml})(\mathrm{m} \pm \mathrm{SEM} ; p>0.05)$. The mean peak values were respectively $18.0 \pm 0.8 \mathrm{mmol} / 1 \quad(325 \pm$ $15 \mathrm{mg} / 100 \mathrm{ml}) ; \quad 17.7 \pm 0.9 \mathrm{mmol} / 1 \quad$ (319 $\pm 16 \mathrm{mg} /$ $100 \mathrm{ml}) ; 17.5 \pm 0.8 \mathrm{mmol} / 1(315 \pm 15), p>0.05$ and the mean areas of increment above starting values were $807.4 \pm 101.2, \quad 740.0 \pm 83.4$ and $705.7 \pm 83.0 \mathrm{mmol}$ $\times 1^{-1} \times \min , F=0.89$, NS. Peak times were also comparable after the three breakfasts respectively: $86 \pm 6$; $91 \pm 9$ and $82 \pm 7 \mathrm{~min}(p>0.05)$.

Concerning plasma insulin levels (Table 4), we were there again unable to discover any significant difference between the three breakfasts, i. e. respectively and in the same order (bread, sucrose, and honey) for fasting insulin levels: $11.9 \pm 2.0 \mathrm{mU} / 1 ; 11.8 \pm 1.0 \mathrm{mU} / 1 ; 12.7 \pm$ $2.0 \mathrm{mU} / 1(\mathrm{~F}=0.99, p>0.05)$; likewise mean peak insulin values were $33.6 \pm 4.0 \mathrm{mU} / 1 ; 34.0 \pm 4.5 \mathrm{mU} / 1$; $36.3 \pm 4.4 \mathrm{mU} / 1$ (NS) and mean areas of insulin increment above starting values were $2324 \pm 388,2313 \pm 355$ and $2306 \pm 397 \mathrm{mU} \times 1^{-1} \times \min (\mathrm{F}=0.41$, NS $)$. Peaks ocurred again at comparable times in the three groups: $99 \pm 10,94 \pm 9$ and $86 \pm 13 \mathrm{~min}$ (NS).

In group B results were similar. Mean fasting (starting) plasma glucose values were also comparable in the three situations: $6.7 \pm 0.3 \mathrm{mmol} / 1(120 \pm 5 \mathrm{mg} / 100 \mathrm{ml})$ with the white bread supplement; $6.5 \pm 0.5 \mathrm{mmol} / 1$ $(117 \pm 9 \mathrm{mg} / 100 \mathrm{ml})$ with sucrose; $6.4 \pm 0.5 \mathrm{mmol} / 1$ $(115 \pm 9 \mathrm{mg} / 100 \mathrm{ml})$ with honey $(\mathrm{F}=0.73$, NS). Mean peaking values were $13.9 \pm 0.9 \mathrm{mmol} / 1 \quad(250 \pm$ $16 \mathrm{mg} / 100 \mathrm{ml}) ; 12.8 \pm 0.8 \mathrm{mmol} / 1(230 \pm 14 \mathrm{mg} / 100 \mathrm{ml})$; $12.7 \pm 0.9 \mathrm{mmol} / 1(238 \pm 16 \mathrm{mg} / 100 \mathrm{ml})(\mathrm{NS})$.

Mean areas of glucose increment above starting levels were $796.3 \pm 160.2,755.1 \pm 176.2$ and $730.7 \pm$ $158.0 \mathrm{mmol} \times 1^{-1} \times \min (\mathrm{F}=1.46$; NS $)$. Peaking time was respectively $95 \pm 12,75 \pm 16$ and $77 \pm 11 \mathrm{~min}$ (NS).

As for plasma insulin levels, fasting levels were $24.2 \pm 2.0 \mathrm{mU} / 1 ; 21.5 \pm 4.0 \mathrm{mU} / \mathrm{l} ; 17.2 \pm 4.0 \mathrm{mU} / 1(\mathrm{~F}=$ 0.45 ; NS), peak insulin levels reached $57.5 \pm 10.1 \mathrm{mU} / 1$; $54.8 \pm 6.4 \mathrm{mU} / 1 ; 52.5 \pm 6.3 \mathrm{mU} / 1$ (NS) and mean areas of insulin increment above starting values were respectively $4655 \pm 829 ; \quad 4087 \pm 404 ; \quad 4585 \pm 447 \mathrm{mU} \times 1^{-1}$ $\times \min (\mathrm{F}=0.58$; NS). Lastly, peaking time was: $105 \pm$ $17 \mathrm{~min}, 80 \pm 6 \mathrm{~min}$ and $95 \pm 18 \mathrm{~min}(\mathrm{NS})$.

\section{Discussion}

Contrarily to what might have been expected but consistent with what we have already found in Type 1 and in Type 2 diabetic patients [12], exchanging an isoglucidic isocaloric amount of bread for sugar (sucrose) or honey (glucose and fructose) has no additional hyperglycaemic effect in Type 2 diabetics whether well- or uncontrolled.

Indeed plasma glucose curves were almost perfectly superimposed in each sub-group of patients (group A: poorly controlled, group B: well controlled subjects).

If we consider the increment above starting plasma glucose values, we can see that this increment is comparable for each type of breakfast in the two subgroups of patients (Table 2) which means that the hyperglycaemic effect of a meal (i.e the rise above pre-meal value) seems not to correlate to the degree of diabetic control.

This might be due in part to a greater renal excretion of glucose in the badly controlled subjects where the renal threshold is probably often attained [15] (though this hypothesis has not be verified in these patients), and in particular to a continuous and excessive endogenous production of glucose in greatly insulin-deficient diabetic patients which is not suppressed or altered by meal intake as shown by Pehling et al. [16].

If we now consider plasma insulin fluctuations, we can see that, as expected, insulin secretion is much lower in the uncontrolled diabetics, and their mean increment of insulin secretion above starting values was also significantly lower.

Our study confirms that the breakfast period is the worst one for blood glucose regulation since postbreakfast plasma glucose was above the 2 -h post-midday meal value (which is the most copious meal in our country), both in the badly and in the "well" -controlled subjects even after relatively light breakfasts such as these.

We conclude that, in acute conditions, substitution of part of a mixed meal by a reasonable amount of simple, currently available sugars has no deleterious effect on blood glucose regulation and insulin secretion in Type 2 diabetic patients. To what extent such sugars could be allowed in Type 2 diabetic patients, very often obese, is to be discussed cautiously. They could at least be put to the test when negotiating with the patients a better commitment to the compulsory hypocaloric diet. The validity of these conclusions now have to be confirmed on long-term follow-up studies.

\footnotetext{
Acknowledgements. We would like to thank Mme Bros, Mlle Chevalier, Mme Desplanque, Mme Boillot and Dr. Letanoux for their help in this work and Mme F. Leblanc for her secretarial assistance. This study was supported by a grant from the University Pierre et Marie Curie, Paris VI and by the Benjamin Delessert Foundation.
} 


\section{References}

1. American Diabetes Association (1979) Principles of nutrition and dietary recommendations for individuals with diabetes mellitus. Diabetes 28: 1027-1030

2. Canadian Diabetes Association (1981) Guidelines for the nutritional management of diabetes mellitus: 1980. J Can Dietet Assoc 42: $110-118$

3. The nutrition sub-committee of the Medical Advisory Committee of the British Diabetic Association (1981) Dietary recommendations for diabetics for the 1980s. In: Cudworth AG, Andreani D, Bodansky HJ, Squaduto G, eds. Diabetes and its late complications. John Libbey, London, pp 157-167

4. Dehlinger C, Laffitte A, Truffe P, Slama G, Costagliola D, Celanie E (1983) Goût sucré et consommation de sucres simples chez 88 diabétiques de type 1 et de type 2. Diabète Metab 9: 169

5. Crapo PA, Reaven G, Olefsky J (1976) Plasma glucose and insulin responses to orally administered simple and complex carbohydrates. Diabetes 25:741-747

6. Jenkins DJA, Wolever TMS, Taylor RH, Barker $\mathrm{H}$, Fielden $\mathrm{H}$, Baldwin JM, Bowling AC, Newman HC, Jenkins AL, Goff DV (1981) Glycemic index of foods: a physiological basis for carbohydrate exchange. Am J Clin Nutr 34: 362-366

7. Spaethe R, Brinck UC, Sabin J, Wubbens D, Otto H (1972) Echange des hydrates de carbone d'après le principe des équivalents biologiques dans le régime pour diabétiques. In: Journées de Diabétologie de l'Hôtel-Dieu. Flammarion, Paris: 253-259

8. Ionescu-Tirgoviste C, Popa E, Sintu E, Mihalache N, Cheta D, Mincu I (1983) Blood glucose and plasma insulin responses to various carbohydrates in type 2 (non-insulin-dependent) diabetes. Diabetologia 24: 80-84

9. Bantle JP, Laine DC, Castle GW, Thomas GW, Hoogwerf BJ, Goetz FC (1983) Postprandial glucose and insulin response to meals containing different carbohydrates in normal and diabetic subjects. N Engl J Med 309: 7-12
10. Slama G, Klein JC, Delage A, Ardila E, Lemaignen H, Papoz L, Tchobroutsky $G$ (1981) Correlation between the nature and amount of carbohydrate in meal intake and insulin delivery by the artificial pancreas in 24 insulin-dependent diabetics. Diabetes 30: $101-105$

11. Mann JI (1980) Diet and diabetes. Diabetologia 18:89-95

12. Slama G, Jean-Joseph P, Goicolea I, Elgrably F, Haardt MJ, Costagliola D, Bornet F, Tchobroutsky G (1984) Sucrose taken during a mixed meal has no additional hyperglycaemic action over isocaloric amounts of starch in well-controlled diabetics. Lancet 2: $122-125$

13. Jersild M (1967) Postprandial blood sugar rise in diabetics. Acta Med Scand suppl 476:101-107

14. Documenta Geigy (1972) Tables scientifiques, 7 edn. Ciba-Geigy SA, Basle

15. Meyer HU, Curchod B, Maeder E, Pahud P, Jequier E, Felber JP (1980) Modifications of glucose storage and oxidation in non obese diabetics, measured by continuous indirect calorimetry. Diabetes 29: 752-756

16. Pehling G, Tessari P, Gerich JE, Haymond MW, Service FJ, Rizza RA (1984) Abnormal meal carbohydrate disposition in insulin-dependent diabetes. Relative contributions of endogenous glucose production and initial splanchnic uptake and effect of intensive insulin therapy. J Clin Invest 74: 985-991

Received: 2 January 1985

and in revised form: 19 March 1985

Dr. G. Slama

Service de Diabétologie

Hôtel-Dieu

1 place du Paris Notre-Dame

75181 Paris Cedex 04

France 